\begin{tabular}{|l|c|c|}
\hline Q1. & \multicolumn{3}{|c|}{$\begin{array}{c}\text { Eurasian Academy of Sciences } \\
\text { Eurasian Art \& Humanities Journal } \\
\text { Volume:1 }\end{array}$} & S: $12-26$ \\
\hline
\end{tabular}

\title{
DURUB-I EMSAL-I OSMANIYYE OF ALI EMIRI EFENDI
}

\section{İslam Küçük *}

Canik Başarı Üniversitesi Fen Edebiyat Fak. *

E-mail: islamkucuk@basari.edu.tr*

Copyright (C) 2015 İslam Küçük. This is an open access article distributed under the Eurasian Academy of Sciences License, which permits unrestricted use, distribution, and reproduction in any medium, provided the original work is properly cited.

\begin{abstract}
Having been lived in the late Ottoman period, known as book-friendly and men of literature as well as ideas, Ali Emiri Efendi's work, called as Durub-1 Emsal-i Osmaniyye, consists of proverbs and idioms written in Ottoman Turkish. In addition, there are approximately one thousand five hundred verses related to proverbs and idioms. Verses are written to the upper part of the related proverbs and idioms at an angle of about 90 degrees. The work has a total of 161 sheets and was written by 'rika', a font of Ottoman Turkish. There is an average of five lines on each page. In the piece, 2440 proverbs and idioms were put down on paper alphabetically (according to the Arabic alphabet) by the author. The work is recorded in three volumes and in numbers 282.,283., and 284. at Ali Emiri Literary Works Department of Millet Written Manuscripts Library in Istanbul. Evaluations and assessments were conducted by taking this copy into account. The verse and proverb examples, which are presented while providing information on the content, structure and style of the work, are taken from a study conducted by Islam KUCUK on the above-mentioned work.
\end{abstract}

Keywords: Ali Emiri, Durub-1 Emsal, Literature, Proverb, Idiom

\section{ALİ EMİRI EFENDİ'NİN DURÛB-I EMSÂL-İ OSMÂNIYYESİ}

ÖZET: Osmanlı Devleti'nin son dönemlerinde yaşamış, bir kitap dostu olarak bilinen, edebiyat ve fikir adamı Ali Emîrî Efendi'nin Durûb-ı Emsâl-i Osmâniyye adlı eseri Osmanlı Türkçesiyle yazılmış atasözleri ve deyimlerden oluşmaktadır. Ayrıca, eserin içerisinde bu atasözleri ve deyimlerle ilgili yaklaşık bin beş yüz beyit mevcuttur. Beyitler, ilgili atasözü ve deyimlerin üst kısmına yaklaşık 90 derecelik bir açıyla yazılmıștır. Eser, toplam 161 yapraktır ve Osmanlı Türkçesinin bir yazı tipi olan 'rika' ile yazılmıştır. Her bir sayfada ortalama beş satır bulunmaktadır. Eserde, 2440 adet atasözü ve deyim yazar tarafindlan alfabetik olarak (Arap alfabesine göre) kaleme alınmıştır. Eser, İstanbul'daki Millet Yazma Eser Kütüphanesi Ali Emiri Edebiyat Eserleri Bölümü'nde 282., 283. ve 284. numaralarda üç cilt hâlinde kayıtlıdır. Yapılan tespit ve değerlendirmeler bu nüsha dikkate alınarak gerçekleştirilmiştir. Eserin muhteviyatı, şekil yapısı ve üslubu hakkında bilgi verilirken sunulan beyit ve atasözü misalleri, malum eser üzerinde İslam KÜÇÜK tarafından yapılan çalışmadan alınmıştır. (KÜÇÜK, 2014)

Anahtar Kelimeler: Ali Emîrî, Durûb-1 Emsâl, Edebiyat, Atasözü, Deyim 


\section{Giriş}

Eski Türk Edebiyatı alanında akademik düzeyde yapılan çalışmalar metin neşri, metin şerhi, metin tahlili ve edebiyat tarihi vb. şekilde sıralanabilir. Eski Türk Edebiyatı'ndaki metin çalışmalarının en önemli amacı, eski metinlerin doğru bir şekilde oluşturulması, yeni harfli metin olarak günümüz okurlarına ve araştırmacılarına aktarılmasıdır. Bu doğrultuda öncelikli divan olmak üzere tezkire, mesnevi vb. birçok çalışmanın yeni harfli metin olarak kurulumu sağlanmaktadır. Bu sayede Eski Türk Edebiyatı dönemine ve geçmiş kültürümüze ait bilgilerin tanıtımı yapılmaktadır.

$\mathrm{Bu}$ alandaki en önemli çalışmalardan birisi de Osmanlı döneminde yazılmış olan Durûb-ı Emsâl-i Osmâniyye'lerdir. Bu eserler, genç nesillerin eğitiminde ciddi manada ehemmiyet arz eden atasözlerinden ve deyimlerden oluşmaktadır. Atasözleri, nasihatlerin ve tecrübe aktarımının en yoğun olarak kendisine yer bulduğu, manevi değeri oldukça yüksek sözlerdir. Atasözleri, bu eserlerde kendisine düz yazıdan daha ziyade şiirlerde yer bulmaktadır. Kaleme alınmış olan çalışmalardan bazıları başlı başına bir kitap oluştururken bazıları da mecmualarda şiirler hâlinde yer almaktadır. Bilhassa kitap hâlinde olmayan ve mecmuaların derinliklerinde kalmış atasözü muhteviyatlı pek çok şiir, üzerlerinde ciddi anlamda çalışma yapılarak genç nesillerin istifadesine sunulamamıştır. Bu alanda yapılacak çalışmaların sayısı arttıkça, genç nesillerin geçmiş ile gelecek arasında köprü kurabilmeleri sağlanacaktır. Ali Emiri Efendi'nin Durûb-ı Emsâl-i Osmâniyye'si adlı eserin de bu alana önemli ölçüde katkı sağlayacağ 1 ve alandaki araştırmacılara yeni ufuklar açacağı düșünülmektedir.

\section{Atasözleri ve Deyimler}

Atasözleri, ataların uzun denemelere dayanan yargılarını genel kural, bilgece düşünce ya da öğüt olarak düsturlaştıran ve kalıplaşmış biçimleri bulunan kamuca benimsenmiş özsözler; (Aksoy, 1988: 37) beşer cemiyetiyle beraber doğmuş, onunla birlikte oba, boy ve oymak olarak asırlarca göçebe hayatı yaşamış ve nihayet gelişip özleşerek de ulus hâline yükselmiş, medenileşmiş törelerdir; (Dilçin, 2000: 15) atasözleri ve deyimler, bir milletin kültür seviyesini, hayat tecrübesini, dünyaya bakışını gösterirler; (Yetiş, 1993: 11) atasözleri, eskiden sav, mesel, darb-1 mesel olarak tabir edilen konuşma dilinde ve manzum, mensur yazı dilinde yaşayan hikmet dolu, nasihat dolu eğitici öğretici özelliklere sahip veciz sözlerdir, deyimler ise yine konuşma dilinde manzum ve mensur yazılarda sıkça rastlanılan, çoklukla birkaç kelime veya bir kısa cümle ile teşbih, istiare, mecaz, kinaye sanatları kullanılarak bir meramı anlatan, bir hadiseyi tasvir eden sözlerdir; (Beyzadeoğlu, 2003: 1) her milletin kendi dilinde atasözleri ve deyimleri vardır ve o dile ayrı anlamlar kazandıran, veciz, düşündürücü, öğretici, öğütleyici ve yol gösterici unsurlardır, atasözleri ve deyimler, her milletin kendi hayatlarının her alanında kullandıkları, evde, eğitim kurumlarında, sokakta, çarşıda, pazarda, tarlada, iş yerinde zevkle söyleyegeldikleri ve dillerinden düşürmedikleri hazineleridir; (Yazıc1, 2003: 21) atasözleri, bir ulusun, geniş halk kitlelerinin yüzyıllar boyunca yaşadığı deneyim, gözlem ve bunlardan doğan düşüncelere dayanan, genel kural ve düstur niteliği taşıyan veya bir doğruyu ortaya koyan, söyleyeni unutulduğu için halkın ortak malı olan (anonim), kısa, özlü ve kalıplaşmış, içinde yargı (hüküm) bulunan bir tümce değerindeki sözlerdir; (Aktaş, 2004: 13) atasözü, toplumun yüzyılların verdiği deneme, düşünce ve özleminden doğmuş, kurallaşmış, kalıplaşmış, her yerde her zaman doğru olanı söyleyen ve hüküm bildiren özlü sözlerdir. (Su, 1971: 5). 
Atasözleri ile deyimleri birbirinden ayıranlar ve bu suretle kitaplarında bir tasnif yapan yazarlar olmuştur. Ancak vücuda getirdikleri kıymetli eserlerinde bu farkı çok güzel ifade ettikleri hâlde tasnifte hataya düşmüşler, deyimlerle atasözlerini ister istemez birbirine karıştırmışlardır. (Tülbentçi, 1963: 6) Ömer Asım Aksoy da deyimler ve atasözlerinin birbirine karıştırılması noktasında şu tespitlerde bulunmaktadır: 'Bizdeki eskiden sav, mesel, tabir diye anılmış olan ve eski, yeni konuşma dillerinde, manzum, mensur yazılar arasında kullanılmış ve kullanılmakta bulunan atasözleriyle deyimler, birçok kimselerce derlenmiş ve kitap olarak yayımlanmış ise de ne gibi özellikleri bulunan söze atasözü, ne gibi özellikleri bulunan söze deyim denilmek gerektiği ciddi olarak incelenmemiştir. Başta Şinasi'nin Durûb$\iota$ Emsâl-i Osmâniyye'si olmak üzere bütün derlemeler, atasözleri adı altında verilen deyimlerle, deyim adı altında verilen atasözleriyle ya da ne atalarsözü, ne deyim olan birtakım laflarla doludur. Bu karışıklık sürüp gitmektedir. (Aksoy, 1988: 13) Aynı şekilde Aydın Su da atasözleri ile deyimler arasındaki farkı verdiği misallerle ortaya koymaktadır: 'Atasözü bir hüküm bildirir, değişmez bir doğruyu söyler. Deyimse bir durum bildirir, bir kavram belirtir, kesinkes değildir. "Et tırnaktan ayrılmaz." bir atasözüdür, bir hüküm bildirmekte, bir doğruyu belirtmektedir. "Et tırnak olmak" ise bir deyimdir, "çok yakın ilgi kurmak" anlamındadır. "Bol bol yiyen bel bel bakar" yine bir atasözüdür, "bel bel bakmak" ise bir deyimdir. (Su, 1971: 6)

Atasözleri sosyal hayatın bir parçası olduğu için sözlü edebiyat geleneği ile mevcudiyetini sürdürmüş ve yazılı edebiyatın başlangıcı ile varlığını devam ettirmiştir. Süreyya Beyzadeoğlu atasözlerinin başlangıcı ve kısa tarihçesi ile ilgili olarak eserinde şu bilgilere yer vermektedir: "Atasözlerinin başlangıcı, ilk yazılı edebiyat ürünümüz sayılan Orhun Yazıtları'na dayanmaktadır. Bu abidelerde "Ağaç yaşken eğilir." anlamında bir atasözü vardır. XI. yüzyılda yazılan Divân-ı Lugâti't-Türk'te 300'e yakın atasözü bulunmaktadır. Yine aynı yüzyılda yazılan Kutadgu Bilig, bir yüzyıl sonra yazılan Atabetü'l-Hakayık'ta, XIII.-XIV. yüzyıllarda yaşayan Yunus Emre, Gülşehri, Âşık Paşa'nın eserlerinde atasözü ve deyim ihtiva eden beyitlere rastlanmaktadır. (Beyzadeoğlu, 2003: 1) Numan Yazıcı da atasözlerinin tarih içindeki sürecini şu şekilde izah etmektedir: 'Yazıya geçmiş ilk atasözü örneklerine Mezopotamya'da bulunan tabletlerde rastlanmıştır. Bu tabletlerdeki atasözleri, tarihin en eski atasözleri olarak ayrı bir değer taşır. Mukaddes kitaplarda da atasözlerine rastlanmaktadır. Tevrat'ta "Hz. Süleyman'ın meselleri” diye anılan sözlerle bunlar arasında bir ilgi bulunduğu kabul edilir. İslamiyet döneminde gerek Kur'an-1 Kerim'de gerekse hadislerde de ilk önce geldiği toplumu, daha sonra da yayıldığı toplumları uyarıcı, öğütleyici pek çok örnekleri bulunmaktadır. (Yazıcı, 2003: 21) Feridun Fazıl Tülbentçi de atasözlerinin tarihçesi ile ilgili şu bilgileri aktarmaktadır: "Türk edebiyatında atalarsözü mesnevi tarzında ve on ikinci yüzyıldan sonra başlamış, bilahare edebi bir sanat halini almıştır. On beşinci ve on altıncı yüzyıl şairlerinden Sâfi, Visâli, Ahmed Paşa, Zâti ve Necâti gibi üstatlar, yazdıkları gazel ve kasidelerde atasözleri kullanmayı ihmal etmemişlerdir. On altıncı asır başlarında yaşamış, sipahi sıfatı ile muharebelere iştirak etmiş, Yavuz Sultan Selim Han'ın zaferlerine şahit olmuş bulunan Güvahi'nin 1891 beyitli "Pendnâme-i Güvahi" adını taşıyan risalesi, atasözleri bakımından çok zengindir. " (Tülbentçi, 1963: 9)

Atasözlerinde, ait oldukları toplumların kültürel, ahlaki, sosyal, manevi ve inanç temelli tüm değerlerini bulmanız mümkündür. Bir bakıma toplumların aynası gibidirler ve çok zengin bir anlam çeşitliliğine sahiptirler. İşte bu noktada bazı atasözlerinin de ifade ettikleri anlam itibariyle, toplumun değer yargilarıyla bire bir örtüştügünü söylemek mümkün değildir. Feridun Fazıl Tülbentçi bu hususla ilgili şu tespitte bulunmaktadır: 'Atasözleri arasında iyileri 
olduğu gibi fenaları da vardır. Birbirlerine tamamen zit olanlar da mevcuttur. Mesela fena atasözleri arasında: "Doğru söyleyeni dokuz köyden kovarlar", "Yağmur yağarken küpünü doldur", "Ben öldükten sonra taş taş üstünde kalmasın", "Sabahki yiyeceğini bugünden düşünme", "Altın anahtar kale kapılarını açar", "Paralı adamdan dağlar korkar", "Bekârlık gibi sultanlık olmaz", "İtte vefa olur avrette vefa olmaz", "Yiğitliğin silahı inkârdır", "El öpmekle ağız aşınmaz", "İnanma dostuna saman kor postuna" gibi yalancılı̆̆ı, hodgâmlığı, lakaytlı̆̆ı, anaforculuğu, aile düzensizliğini, paranın menfi rolünü, müdarayı ve vefasızlığı mübah gösteren bu ve buna benzer atasözleri ilk bakışta fenalığı teşvik eder mahiyette görülürse de yerinde söylendiği takdirde onlardan da bir ibret dersi çıkarmak mümkündür. (Tülbentçi, 1963: 6-7) Ömer Asım Aksoy anlam yönüyle birbiriyle çelişen ve olumsuz manalar içeren atasözleriyle ilgili şunları belirtmektedir: 'Atasözleri içinde anlamları birbirine aykırı olanlar vardır. Her atasözü bir kural olduğuna göre bu çelişik sözlerden her biri nasıl kural sayılabilir? Bu soruya cevap verebilmek için görüp geçirdiğimiz olayların çelişmelerle dolu olduğunu düşünmek gerekir. Bunları belirten kurallar da şüphesiz öyle olacaktır. Bundan başka aynı olay, değişik koşullar altında ayrı ayrı sonuçlar verebilir. O zaman birbirini tutmayan düsturlar ortaya çıkar. Nitekim yalan söylemenin kötü sonuçlar vereceğini bildiren atasözleriyle birlikte doğru söylemenin kötü sonuçlar vereceğini bildiren atasözleri de yaşamaktadır: "Yalancının evi yanmış, kimse inanmamış", "Yalancının mumu yatsıya kadar yanar", "Doğru söyleyeni dokuz köyden kovarlar", "Doğru söyleyenin tepesi delik olur". (Aksoy, 1988: 29-30)

Atasözlerinin, bulunduğu zemin ve devre göre farklılaştıklarını söylemek mümkündür. Aynı anlamı ifade eden birçok atasözünün farklı şekillerde telaffuz edildiğini, az da olsa bazı kelimelerin değişikliğe uğradığını görmekteyiz. Bu durumla ilgili olarak Uğur Başaran şu örneklere yer vermektedir: 'Söz gelimi, "Oturduğu ahır eskisi, çağırdığı İstanbul türküsü” ve "Oturduğu ahır eskisi, söylediği İstanbul şarkısı" atasözlerini düşündüğümüzde her iki atasözünün aynı işleyiş sistemine sahip olduklarını ancak varyantlaşarak değiştikleri görülmektedir. Söyleniş bağlamları düşünüldüğünde muhtemelen "çağırdı ğı İstanbul türküsü" kelimeleriyle biten atasözünün daha çok ilçe, kasaba ve köylerde; "söylediği İstanbul şarkısı" sözcükleriyle biten atasözünün ise daha çok şehir merkezlerinde yaygın olarak kullanıldığı ihtimali kuvvetlidir. Bu da bize göstermektedir ki atasözlerinde meydana gelen değişim ve dönüşüm, farklılaşma ve benzer metinlerin ortaya çıkması tesadüfi bir durum değil; yukarıda belirtildiği üzere sosyo-kültürel durumlara ve pozisyonlara göre şekillenen kabuller sonucu ortaya çıkan bir durumdur.' (Başaran, 2013: 757-770)

\section{Osmanlı Döneminde Kaleme Alınan "Durûb-ı Emsâller"}

Osmanlı döneminde; toplumun kültürel, geleneksel, dil ve manevi değerlerinin birikimi olan atasözleri ve deyimlerin yazılmış olduğu eserlere 'Durûb-ı Emsâl' adı verilmiştir. Bu ifade, 'örneklemek (misal getirmek)' anlamına gelmektedir. Günümüzde ise yerini büyük bir oranda 'atalar sözü’ veya 'atasözü' ibarelerine bırakmıştır.

Arapça bir kelime olan 'el-mesel' veya 'el-misl' "benzeme, benzetme, bir şeyin benzerini nakletme" demektir. Ayrıca sıfat, delil, kısas, ibret alınacak bir cezayı vernek... gibi manaları da vardır. Çoğulu 'emsâl' gelir. Her ne kadar bazı Arap alimleri intisap manasına gelen 'müsûl' kökünden geldiğini söyleseler de Muallim Naci'nin de belirttiği gibi tarif ve açıklamalardan kelimenin örnek manasına gelen 'misâl' kökünden geldiği genel kabul 
görmüştür. (Yazıc1, 2003: 23) Aslında 'darb-1 mesel' Arapça iki kelimden oluşan bir terkiptir. "Mesel getirmek, örnek vermek, içinde bulunulan hâle uygun bir söz ya da atasözü söylemek, misâlin vurgulanması" demektir. Çoğulu 'durûb-1 emsâl/misâllerin vurgulanması'dır. (Yazıcı, 2003: 25).

Osmanlı döneminde tespit edilen yedi adet 'Durûb-1 Emsâl' mevcuttur:

1. Pend-nâme-i Güvâhî: 15. yüzyıl şairlerinden Attar'ın Pend-nâme'sini örnek alarak yazdığ 1 bu eserde atasözleri ve deyimleri ihtiva eden kendisine ait 450 beyit bulunmaktadir.

2. Manzum ve Musavver Durûb-ı Emsâl: 16. yüzyıla ait müellifi bilinmeyen bu eserde 267 atasözü ve deyimle bu atasözü ve deyimleri ihtiva eden müellife ait 289 beyit bulunmaktadır. 29 minyatürün yer aldığı bu eser, Günay Kut tarafından incelenerek yayımlanmıştır.

3. Manzûme-i Durûb-ı Emsâl: 17. yüzyıl şairlerinden Edirneli Hıfzi, bu eserinde sade söyleyişli atasözü ve deyimlerin, zurefâ meclislerinde rağbet bulması için, süslenmesi ve manzum olarak söylenmesi gerektiğini ileri sürerek ilgili atasözü ve deyimi vermeden ve mahlas da belirtmeden değişik Divan şairlerine ait 616 atasözü ve deyim ihtiva eden süslü mısraları bir araya toplamıştır. Bu mısraların bir kısmı da kendisine ait olmalıdır.

4. Darb-ı Meseller ve Uygun Beyitler: 19. yüzyıla ait bir mecmuanın 50-100. sayfaları arasında, müstensihi belli olmayan 490 atasözü ve deyim ve her biri için Divan şairlerinden seçilmiş aynı muhtevada yine 490 beyit bulunmaktadır.

5. Durûb-ı Emsâl-i Osmâniyye: Şinasi'nin tespit ettiği 2500 atasözü ve deyim ve bunların bir kısmını karşılayan değişik Divan şairlerinden aldığı beyitleri ihtiva eden bu esere, şairin ölümünden sonra Ebu'z-Ziya Tevfik tarafindan ilaveler yapılarak atasözü ve deyimler biri mükerrer 4004'e, örnek beyitler de 1003'e yükseltilmiştir. Ayrıca eserde Arapça, Farsça ve Fransızca atasözü ve deyimler bulunmaktadır.

6. Durûb-ı Emsâl: Ali Emiri'nin yarım bırakılmış müsvedde üç defter hâlindeki adsız olan eseri muhtevası itibariyle bu adla tanınmıştır. Eserde 2300 atasözü ve deyimle bunları ihtiva eden 2110 beyit bulunmaktadır.

7. Armă̆an: Kronolojik sirayla bu sahada derlenen son Osmanlı eseri ise Edirneli Ahmed Bâdî’nin 5675 atasözü ve deyimle bu atasözü ve deyimleri ihtiva eden 5106 beytin yer aldığı zengin muhtevalı Armağan adlı eseridir. (Beyzadeoğlu, 2002: 350$358)$.

$\mathrm{Bu}$ eserlerle ilgili olarak daha ayrıntılı bilgi edinebilmek için farklı kaynaklara başvurulabilir. (Beyzadeoğlu, 2003; Erenoğlu, 2007; Dülger, 2013)

\section{Yazma'nın Tanitımı}

Durûb-ı Emsâl-i Osmâniyye adlı yazmanın bilinen tek nüshası mevcuttur. Eser, Millet Yazma Eser Kütüphanesi Ali Emiri Edebiyat Eserleri Bölümü'nde üç cilt hâlinde 282., 283. ve 284. numaralarda kayıtlıdır.

Yazma, Ali Emiri'nin kendi hattı ile kaleme alınmıştır. Rik'a olarak adlandırılan bir yazı türüdür. Yazma, üç ciltten oluşmaktadır. Birinci cilt 54 varaktır. Varak $41^{\text {b' }}$ den itibaren 27 sayfa muhasebe kaydı mevcuttur. Muhasebe kayıtlarının olduğu bu bölümde bir varak boş bırakılmıştır. Arap alfabesindeki sıralamaya göre oluşturulmuş bu cilt, 'elif, be, pe ve te' 
harflerini almış oldukları harekelere göre ihtiva etmektedir. Cildin telif tarihi ile ilgili herhangi bir kayıt mevcut değildir. İkinci cilt 60 varaktır. Arap alfabesine göre sırasıyla 'cim' harfi ile 'kaf' harfi de dahil olmak üzere bu iki harf arasındaki bütün harfler aldıkları harekelere göre sıralanmıştır. Üçüncü cilt 61 varaktır. Bu ciltte 'kaf' harfinden başlamak üzere Arap alfabesinin son harfi olan 'ye' harfine kadar giden bir siralama mevcuttur. Sınıflandırma, diğer ciltlerde olduğu gibi harflerin aldıkları harekelere göre yapılmıştır.

Üç cildin tamamı da Ali Emiri'nin kendi hattı ile kaleme alınmıştır ve hiçbirisinde eserin telif tarihi ile ilgili bir kayıt mevcut değildir. Ali Emiri'nin Durûb-ı Emsâl-i Osmâniyye'si, kendisinden önce yapılan derlemelerde de olduğu gibi Arap harflerine göre düzenlenmiştir. Her harf de kendi arasında "elif ile", "fetha ile", "kesre ile", "zamme-i sakîle-i mebsûta" ve "zamme-i hafîfe-i mebsûta" şeklinde yine alfabetik olarak sıralanmıştır. Ali Emiri'nin Durûbı Emsâl-i Osmâniyyesi'nde 2440 madde başı bulunmaktadır ve eser toplam 161 varaktır. Satır sayısı varaklara göre farklılık göstermekle beraber ortalama dörttür. Atasözleri ve deyimlerle ilgili beyitler, müellif tarafından atasözleri ve deyimlerin üst kısmına 90 derecelik bir açı ile dikey bir şekilde yazılmıştır. Eserde Arapça ve Farsça atasözleri de bulunmaktadır. Bunlar müellif tarafindan 'Arab̂̀' ve 'Fârisî̀' şeklinde ifade edilmiştir. Halk arasında ciddi manada ehemmiyet arz edecek derecede kendisine yer bulmuş ifadeler, müelliff tarafından 'beyt- $i$ meşhur' ve 'mısra-ı meşhur' şeklinde belirtilmiştir. Ayrıca Ali Emiri'nin kaynağı belli olan bazı veciz ifadeleri madde başı yaptığı görülmektedir. Bunların arasında ayet, hadis ve şairi belli olan misralar mevcuttur. Eserin tamamı müsvedde hâlindedir. En dikkat çekici özelliklerinden birisi de müellifin, Hıfzî'nin Manzûme-i Emsâl' inde mevcut birçok atasözüne bu eserde yer vermesidir.

Yazma'nın başı:

Âb-1 pâke ne zarar vakvaka-y1 kurbagadan $1^{\mathrm{b}} / 1$

Yazma'nın sonu:

Y1lanla oyun olmaz $161^{\mathrm{b}} / 3$

\section{Metin}

Eserde, atasözü ve beyit yoğunluğunun bazı sayfalarda oldukça fazla bazılarında ise az olduğu görülmektedir. 

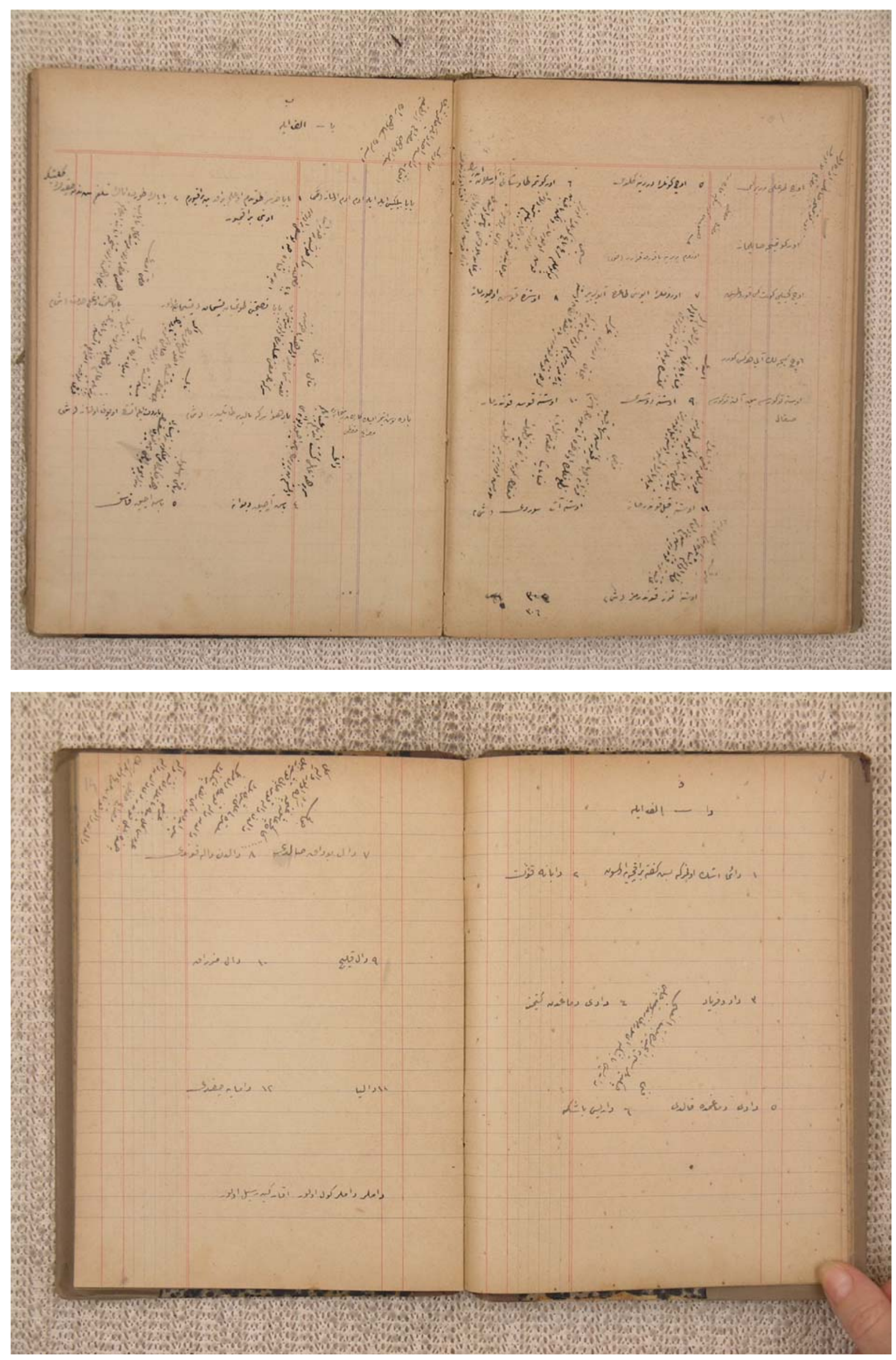
Ali Emiri, eserinde Hıfzi'nin Manzûme-i Emsâl adlı eserinden 467 adet atasözüne yer vermiştir. Bunlardan bazıları şunlardır:

Nâmı yâd olur erüñ fevtiyle esbüñ sâhası (Hıfzî: $M . E^{l}$ : s. 22)

[= Er kişinin gitmesiyle, at meydanının ismi hatırlanır.]

Lu'bı olmaz âteş ile penbenüñ (Hıfzî: M. E: s. 20)

[= Ateş ile pamuğun oyunu olmaz. ]

Tîr-i endâhte avdet etmez (Hıfzî: M. E: s. 11)

[= Atılmış ok geri gelmez. ]

Merâret telhi mahv eyler meseldür (Hıfzî: M. E: s. 20)

[= Atasözüdür: “Ac1 acıyı bastırır.”]

Gürisne hırs oynamaz meşhurdur (Hıfzî: M. E: s. 19)

[= Meşhurdur: “Aç ayı oynamaz.”]

Kendini aç mâkiyân enbâr-1 cevde zann eder (Hıfzî: M. E: s. 19)

[= Aç tavuk kendisini arpa anbarında zanneder.]

Kıragı telh-bâdıncânı çalmaz (Hıfzî: M. E: s. 17)

[= Acı patlıcanı kırağı çalmaz.]

Cânum efendi açma kutunuñ kapagını (Hıfzî: M. E: s. 11)

[= Canım efendim! Kutunun kapağını açma.]

Cüst-cû eden bulur Mevlâsını (Hıfzî: M. E: s. 11)

[= Arayan Mevla'sinı bulur ]

Kılleti fehm etmeyen bilmez kezâlik kesreti (Hıfzî: M. E: s. 18)

[= Azlığı anlamayan keza çokluğu da bilmez.]

Killet ekser tâbi-'i bisyâr olur (Hifzî: M. E: s. 18)

[= Az, çoklukla çoğa tâbî olur. ]

Makâl-i ehl-i hünerdür bu az olan öz olur (Hıfzî: M. E: s. 21)

[= Hüner ehli insanların sözüdür bu: 'Az olan öz olur.' ]

Dehânında aceb bakla ter olmaz (Hıfzî: M. E: s. 13)

[= A ğzında bakla ıslanmasa buna şaşılır mı?]

Zâr u giryân olmayan ma'sûma vermezler meme (Hıfzî: M. E: s. 14)

[= Ağlamayan masuma meme vermezler.]

\footnotetext{
${ }^{1}$ Kısaltma, Hıfzî́nin "Manzûme-i Emsâl" adlı eserini ifade etmektedir.
} 
Sarf-1 mâla bakma kâruñ hâsıl olmasına bak (Hıfzî: M. E: s. 16)

[= Malın harcanmasına bakma, işin olmasına bak]

Kem harı bulınca olursuñ süvâr (Hıfzî: M. E: s. 19)

[= Alçak eşeği bulunca sen de binici olursun.]

Zer misâli nîknâmuñ etme mis (Hıfzî: $M . E$ : s. 14)

[= Altın gibi olan güzel namını bakıra çıkarma.]

Mâderin seyr eyleyüp al duhterin (Hıfzî: M. E: s. 21)

[= Anasını görüp kızını al.]

Şîr-i mâder sevdigüm dahı dehânuñda kokar (Hıfzî: M. E: s. 15)

[= A sevdiğim! Hâlâ ağzında anne sütü kokar.]

Ne hoş meseldür olur tu'mî-i şikâr lezîz (Hıfzî: M. E: s. 22)

[= Ne güzel bir atasözüdür: “Av lokması leziz olur.”]

Kamer rûşen hisâb ise mu'ayyen (Hıfzî: M. E: s. 18)

[= Ay parlak hesap ise belli.]

Bunun yanısıra Ali Emiri'nin; eserinde Farsça atasözü, beyit ve mısralara yer verdiği görülmektedir.

Kadr-i zer zerger şinâsed kadr-i gevher gevheri

Kadr-i gül bülbül şinâsed kadr-i Kanber-râ Alî

[= Altının değerini kuyumcu, elmasın değerini ise mücevherci bilir. Gülün değerini bülbül, Kanber'in değerini ise Ali bilir.]

Pûyîden-i râh-1 to be ser ger dehedem dest

Ez şâdî-i ân pây neyâyed bezeminem (Molla Sâmî) yere değmez.]

[= Senin yolunda ellerim üzerinde yürümeye çalışıyorum. Sevindiğim için ayaklarım

Ne behr-i derûn omid ya in çeşm-i hûn-feşân bestem

Nazar begeyr-i tosifet behr-i ân bestem

[= İçimi değil, bu ağlayan gözümü kapatmışım. Niyetim seni övmekten başka bir şey değildir.]

Azm-i dîdâr-1 to dâred cân-1 ber leb âmede

Bâz gerded yâ berâyed çîst fermân-1 şoma (Hâfız)

[= Çıkmak üzere olan canım seni görmek istiyor. Çıksın mı, kalsın mı, nedir buyruğunuz?] 
Kadr-i zer zerger şinâsed kadr-i gevher gevheri

Kadr-i gül bülbül şinâsed kadr-i Kanber Alî

[=Altının değerini kuyumcu, elmasın değerini ise mücevherci bilir. Gülün değerini bülbül, Kanber'in değerini ise Ali bilir.]

Helâk-i har boved seg râ arûsî $10^{\mathrm{a}} / 6^{2}$

Dest-ber-bâlâ-yı dest $11^{\mathrm{b}} / 1$

Herkes be-kâdr-i h'îş giriftâr-1 mihnet est $144^{\mathrm{b}} / 2$

Berekât-1 Halîlü'r-Rahmân bâd

[= Halil İbrahim bereketi olsun.]

Dîvâne menem ber ser dîvâne kalem-nîst

[= Ben deliyim, delinin başının üstünde kaleme gerek yok.]

Zâr eger nîk neşenîd heme kes nerâs ast

[= Zar iyi dönerse herkes usta tavla oyuncusu olur.]

Morg-1 zîrek çon be dam ofted

[= Zeki bir kuş tuzağa düştüğünde.]

Be deryâ dürr menâfi' bî-şumâr est

Eger h ${ }^{\mathrm{V}}$ âhî selâmet der kenâr est

[= Denizde inci gibi yararlı olan nesneler sayısızdır. Eğer sağlık istiyorsan inci hemen yanındadır.]

Buved ü mîşeved ü bâşed ü âmed şud ile

Fârisî oldı sanur yapdıgı saçma-yı sühan

Sünbül-zâde Vehbî( Ez Kasîde-i Kelâmiyyee): Dîvân: K. 51/80

[= Olur, olacak, hayhay, tamam diyerek. Söylediği saçma sözlerin Farsça olduğunu zanneder.]

2 Rakamlarla ifade edilen bölümün ilk kısmı "10a" atasözü, beyit veya mısranın varak numarasını; ikinci kısım ise " 6 " satır numarasını göstermektedir. Makaledeki diğer kullanımlar da bu şekildedir. 
Zinhâr şeref ze yerek bîrûn neşeved

Ki âvâz-1 dohul şenîden ez dûr hoş est (Şerefe'd-dîn Yezdî)

[= Dikkatli ol, şerefini kaybetme! Davulun sesi uzaktan hoş gelir.]

Çinân tûtî sıfat hayrân-1 ân âyîne-i rûyem

Sühan mîgûyedem ammâ nemîdânem çe mîgûyem

[= Bir papağan gibi yüz aynasına öyle hayranım ki konuşuyorum; ancak ne söylediğimi bilmiyorum.]

Şîvehâ mi-koned ke har nekoned

[= Öyle bağırıyor ki eşek bile o şekilde bağıramaz.]

Ez-bâd-1 hevâ âmed ü bâ-bâd-1 hevâ reft

[= Havadan gelen havaya gider.]

Ayrıca, Ali Emiri'nin Yazma'da Hadis-i Şeriflere, Arapça atasözü ve beyitlere de yer verdiği görülmektedir.

A'kâbihâ sümme tevekkül

[= Gerekeni yap, gerisini Allâh'a bırak.]

Rûm eli urmagla açılur $65^{\mathrm{a}} / 3$

Huz mâ safầ da' mâ keder $53^{\mathrm{b}} / 3$

İlâ merfûk illâ rab $11^{\text {b}} / 4$

El-Cennetü tahte akdâmi'l-ümmehâti $11^{\text {b } / 6}$

El-hayru fîmâ vaka'a 12 a 1

El-'ilmü bilâ 'amel ke'ş-şeceri bilâ semer $12^{\mathrm{a}} / 2$

En'necâtü fi's-sadaka $12^{\mathrm{b}} / 6$

Zâde fi't-tanbûrî nagmetün uhrâ $65^{\mathrm{b}} / 1$

Sebbeke men belagake $67^{\mathrm{b}} / 1$

El-hasûdü lâ yesûdü

[= Hasetçi, mutlu olamaz.] 
El-garîku yeteşebbesü bi'şu'âi'ş-şemsi

[= Suya düşen, güneş 1şı̆̆ına sarılır.]

Ed-dünyâ sicnü'l-mü'mini ve cennetü'l-kâfiri (Hadîs-i Şerîf)

[= Dünya müminin Cehennemi, kafirin Cennetidir.]

Ed-dünyâ mezra'atü'l-âhireti (Hadîs-i Şerîf)

[= Dünya, Ahiretin tarlasıdır.]

Küllü men ramâ teffen bi-vech-i semâ'

Raca'a't-teffü bi-vech-i ebedâ

[= Kim gökyüzüne tükürüğünü atarsa, sürekli kendi yüzüne geri döner.]

Levlâ er-rü'yâ ve'l-hulyâ li-mülki'l-fukarâ

[= Rüyâ ile hayal, fakirin malı olmasa...]

Es-Selâmetü fi'l-vahde

[= Huzur ve kurtuluş birliktedir.]

El-kelâmü yecürrü'l-kelâme

[= Laf lafi açar.]

Nahnü nahkümü bi’z-zevâhir

Vallâhi ya'lemü bi’s-serâir

[= Biz, gördüklerimizle hüküm veririz. Sırları (gerçekleri) Allah bilir.]

Ez-zarûrâtü tübîhi’l-mahzûrât

[= Zaruret, yasaklananları mübah k1lar.]

El-ilmü bilâ-'amel ke'ş-şeceri bilâ-semer

[= Amelsiz ilim, meyvesiz ağaç gibidir.]

El-ilmü ‘izzü’d-dünyâ ve şerefü’l-âhira

[= İlim, dünyanın izzeti ahiretin şerefidir.] 
İzâ lem testetı' şey'en fe-da'hu

Ve câvezhü ilâ mâ testetı'u

[= Bir şeyi başaramazsan onu bırak, yapabileceğin işe giriş.]

Lâ ya'lemü'l-gaybe illa'llâh

[= Gaybı, ancak Allâh bilir.]

El-kanâ'atü kenzün lâ-yüfnâ

[= Kanaat, tükenmez hazinedir.]

İzâ kâne'l-gurâbu delîl-i kavm

Seyehdîhim ilâ dâri'l-bevâr

[= Karganın bir kavme işaret olması durumunda onları götüreceği yer, Cehennem'dir.]

İsteşîru zevi'l-ukûl felâ te'sav hum fetündimu (Hadîs-i Şerîfdür)

[= Ey akıl sahipleri! İstişare ediniz. Yoksa onlara isyan eder ve pişman olursunuz.]

Lâ tüs'el 'ani'l-mer'i ve'l-basaru karînehü (Kelâm-1 ‘Alî Kerreme'llâhu vechehü)

[= Er kişi hakkında soru sorma! Zira, göz onun delilidir.]

İttekî şerra men ahsente ileyhi

[= Kime iyilik ettinse onun şerrinden sakın.]

Lehü melekün yünâdî külle leyl

Ledvâ lil-mevti ve enibû'l-harâb

[= Onun bir meleği var; her gece ona: 'Ölümü konuşunuz ve yokluğu arzu ediniz.'diye seslenir.]

İnne'l-lâhu cemîlün yuhibbü'l-cemâl

[= Allah güzeldir, güzeli sever.]

Ke'ş-şemsi fî vasati'n-nehâr

[= Gün ortasında güneş gibidir.]

El-mecâzü kantaratü'l-hakîka 
[= Mecaz, hakikatin kantarıdır.]

Şerefü'l-mekân bi'l-mekîn

[= Mekânın şerefi orada oturanla ilgilidir.]

Nasîbüke yusîbüke [ve-lev kâne tahte'l-cebel]

[= Senin nasibinde varsa dagın altında da olsa olur.]

Fe-fekkir ba'de usrin

Fe-zekkir ba'de yüsrin

[= Zorluktan sonra düşün, kolaylıktan sonra da hatırla.]

Li-külli makâmin makâl

[= Her makamın bir sözü vardır.]

Himmetü'r-ricâl takla'u'l-cibâl

[= Allah dostlarının himmetiyle sultanlar, dağları devirir.]

\section{Sonuç}

Atasözleri ve deyimler, toplumların en önemli dil hazineleridir. Atasözleri daha çok toplumlar tarafından kabul gören duygu ve düşüncelerin, en veciz ve etkin olarak anlatıldığı söz kalıplarıdır. Toplumlar, asırlar boyunca karşılaşmış oldukları hadiselerden ve tecrübelerden elde ettikleri neticeleri, gelecek nesillere aktarmak isterler. Bu aktarımlar, uyarıcı ve ögüt verici mahiyette kısa ve özlü sözler olan atasözleriyle gerçekleştirilmektedir. Atasözlerinde toplumların kültürel, geleneksel ve inanç değerlerinin tüm yönleriyle ele alındığı görülmektedir. Bu sözler, eskiler tarafından 'darb-1 mesel' olarak ifade edilmiştir. Eski Türk Edebiyatı döneminde, şairler tarafından kaleme alınan atasözleri ve deyimlerle ilgili eserlere 'Durûb-ı Emsâl, Durûb-ı Emsâl-i Osmâniyye' gibi isimler verilmiştir. Ali Emiri Efendi'nin eseri de üzerinde farklı açılardan tedkik çalışması yapılabilecek ve bu alana kaynaklık edebilecek temel eserlerden biri kabul edilebilir. 


\section{REFERENCES}

- AKSOY, Ömer Asım (1988). Atasözleri ve Deyimler Sözlüğü: Atasözleri Sözlüğü, İstanbul: İnkılap Kitabevi.

- AKTAŞ, Şöhret Türkmen (2004). Seçme Atasözleri ve Eleştirmeli Açıklamaları, Ankara: Akçağ Yayınları.

- BAŞARAN, Uğur (2013). Atasözlerinin Kalıpsallığg Üzerine, Turkish Studies, sy. 8(9), s. 757-770.

- BEYZADEOĞLU, Süreyya (2002). Osmanlı Dönemi Atasözleri ve Deyimlerinden Divan Şiirinde Yer Alan 20 Atasözü ve Deyim, Türk Kültürü Dergisi, sy. 470, s. 350358.

- $\quad$ BEYZADEOĞLU, Süreyya (2003). Durûb-1 Emsâl-i Osmâniyye, Ankara: Milli Eğitim Bakanlığı Yayınları.

- DİLÇİN, Dehri (2000). Edebiyatımızda Atasözleri, Ankara: Atatürk Kültür, Dil ve Tarih Yüksek Kurumu Türk Dil Kurumu Yayınları.

- DÜLGER, Elif (2013). Ebüzziya Tevfik'in Derlediği Boşnakların Durub-1 Emsali ve Bunların Durub-1 Emsal-i Osmaniyye'deki Varlıkları, Hacettepe Üniversitesi Türkiyat Araştırmaları Dergisi, Güz(19), s. 51-62.

- ERENOĞLU, Dilek (2007): Güvahi'den Günümüze Atasözleri ve Deyimler, Turkish Studies, sy. 4, s. 1150-1167.

- KÜÇÜK, İslam (2014). Ali Emiri Efendi'nin Durûb-1 Emsâl-i Osmâniyyesi: MetinÇeviri-Açıklamalar-Dizin, Yayımlanmamış Doktora Tezi, Bişkek: Kırgızistan-Türkiye Manas Üniversitesi Sosyal Bilimler Enstitüsü.

- SU, Aydın (1971). Açılamalı Atasözleri, İstanbul: Hür Yayınları.

- $\quad$ TÜLBENTÇİ, Feridun Fazıl (1963). Türk Atasözleri ve Deyimleri, İstanbul: İnkılap ve Aka Kitabevleri.

- YAZICI, Numan (2003). Arapça-Türkçe/Türkçe-Arapça Atasözleri ve Deyimler, İstanbul: Rağbet Yayınları.

- YETIŞ, Kazım (1993). Bir İstanbul Hanımefendisi: Samiha Ayverdi'den Türkçe’nin Nakışları, İstanbul: Kubbealtı Neşriyat. 